\title{
Differences between Cystic Fibrosis and Normal Saliva $\alpha$-Amylase as a Function of Age and Sex
}

\author{
BAIBA K. GILLARD, ${ }^{(36)}$ HENRY C. MARKMAN, AND STEPHEN A. FEIG \\ Gwynne Hazen Cherry Memorial Laboratory, Department of Pediatrics, School of Medicine University of California, \\ Los Angeles, California, USA
}

\section{Summary}

$\alpha$-Amylase activity and protein concentration of cystic fibrosis (CF), obligate heterozygote $(\mathrm{H})$, and normal $(\mathrm{N})$ saliva have been evaluated with respect to genotype, age, sex and clinical status. "Factors" present in CF saliva had no detectable effect on salivary amylase activity under reaction conditions optimized for both competitive and noncompetitive inhibition. Tris Itris-(hydroxymethyl)aminomethane] inhibited amylase activity with a $K_{i}=59$ $\pm 10 \mathrm{mM}$, but CF "factors" had no detectable effect on either substrate or Tris binding to $\alpha$-amylase.

$\alpha$-Amylase concentration and protein content of CF saliva had bimodal distributions. Thirty-six percent of the CF patients were found to be amylase hypersecretors, with amylase concentration 3 or more SD above the $\mathbf{N}$ mean. Amylase hypersecretion was marginally correlated with both genetic factors (with parent values, $P=0.075$ ) and clinical status (with Shwachman scores, $P=$ 0.068 ). All the hypersecretors were in the 14-24 year age group. Amylase concentration for this age was significantly higher in $\mathrm{CF}$ samples (mean $\pm \mathrm{SD}), 82 \pm 37 \mathrm{starch}$ units $/ \mathrm{ml}(n=12)$, than in $\mathrm{N}$ samples, $33 \pm 17$ starch units $/ \mathrm{ml}(n=13)$, as measured by the Student $t$-test $(P<0.001)$. Salivary protein content of 14 - to 24-year-old $C F$ males was elevated compared to all other groups $[1.57 \pm 0.76(n=5)$ vs. $0.63 \pm 0.47(n=20)$; Student $t$-test, $P<$ 0.005]. Mean specific activity of male saliva dropped sharply as age increased from 10-15 years, from over 200 to less than 75 starch units $/ \mathrm{mg}$ protein. Mean normal female specific activity values were essentially constant $[97 \pm 50(n=18)$ starch units/mg protein] from 5-30 years of age. $C F$ male specific activity values decreased similarly to the $N$ male values from preadolescence to adolescence, but the mean $C F$ female values peaked later, at 17 years, with a maximum of $171 \pm 58(n=4)$. This is significantly higher than all the other groups in the 16- to 20-year age range: 63 $\pm 30(n=9), P<0.005$. These data emphasize the need for ageand sex-matched controls in all studies of salivary composition.

\section{Speculation}

We were unable to detect any effect of a salivary $\mathrm{CF}$ factor on the enzymatic activity of $\alpha$-amylase. Hypersecretion of salivary $\alpha$-amylase was observed in $36 \%$ of $C F$ patients. This may reflect alterations in secretory function basic to $\mathrm{CF}$, or be secondary to the disease process and result from decreased secretion from the mucous salivary glands or deterioration of pancreatic function.

Cystic fibrosis (CF) is one of the most common lethal genetic diseases of man. The basic defect is not yet known. It is characterized by aberrant exocrine gland activity, progressive pulmonary disability, and gastrointestinal malfunction $(5,31)$. One manifestation of the abnormal exocrine gland activity is the high electrolyte concentration of CF sweat. The sweat salt concentration is the prime diagnostic indicator of CF (14). Pancreatic exocrine function is altered in most but not all CF patients $(5,31)$. Salivary exocrine secretions have also been found to have altered electrolyte and protein content (31). $\alpha$-Amylase (1,4- $\alpha$-D-glucan 4-glucanohydrolase, EC 3.2.1.1) has been reported to be elevated in CF saliva $(2,18)$. Whether the elevated $\alpha$-amylase in $C F$ is a reflection of a general increase in secretory protein concentration or a more specific manifestation of $C F$ remains to be determined.

Ciliary dyskinesia factor(s) (CDF) have been found in the serum, saliva, and urine of CF homozygotes and heterozygotes. These CF body fluids interfere with the normal beat of various ciliated preparations $(9,19,28)$. The salivary CDF appears to be associated with $\alpha$-amylase $(1,8,9,11) . \alpha$-Amylase purified from $\mathrm{CF}$ but not $\mathrm{N}$ saliva possesses CDF activity on oyster gills $(1,21)$. $\mathrm{CDF}$ and $\alpha$-amylase activities coprecipitate from saliva $(8,11)$. The two activities can be separated by extended dialysis (11). The small molecular weight salivary CDF fraction is capable of inhibiting mammalian debranching enzyme $(11,32)$.

Because of the close association of CDF and $\alpha$-amylase in CF saliva, it was of interest to determine whether the presence of CDF could be detected in whole saliva by its effect on $\alpha$-amylase activity. If CDF were found to affect $\alpha$-amylase, this effect could be used to quantitate its concentration in whole saliva. The CDF effect on debranching enzyme indicates that the factor is capable of inhibiting carbohydrase activity (11). The standard saccharogenic assay for $\alpha$-amylase is not affected by CDF in the saliva sample (11). A new assay for $\alpha$-amylase has been developed which should be optimal for detecting CDF if this factor acts as a competitive or noncompetitive inhibitor of $\alpha$-amylase (12). This assay has been used to determine the effect of CDF on salivary $\alpha$-amylase activity. In conjunction with this study, the saccharogenic $\alpha$-amylase activity and the protein concentration of $\mathrm{CF}, \mathrm{H}$, and $N$ saliva samples have also been determined, and analyzed as a function of genotype, age, sex, and clinical status of the saliva donor. The results presented here indicate that the magnitude of the differences between CF and N salivary $\alpha$-amylase and protein are a function of age and sex.

\section{MATERIALS AND METHODS}

CF saliva samples were donated by patients treated at the Cystic Fibrosis Center, University of California at Los Angeles (UCLA) School of Medicine. Obligate heterozygote $(\mathrm{H})$ saliva samples were obtained from parents of CF patients. Normal (N) saliva samples were obtained from donors with no family history of $\mathrm{CF}$. The Human Subject Protection Committee at UCLA has approved the protocol and the Informed Consent Form used for saliva collection.

$\alpha$-Amylase starch activity was determined at $30^{\circ}$ in $50 \mathrm{mM}$ maleate buffer, $\mathrm{pH} 6.5$, using a modification of the Fisher and Stein saccharogenic procedure $(10,12)$. In this reaction mixture, a 1:4000 dilution of saliva is usually used. The starch substrate is at saturating concentration with respect to the reaction rate. The resulting increase in reducing sugar concentration is determined using a modification of the Nelson-Somogyi procedure, with 
glucose as standard (23). Amylase concentration in starch units per liter is defined as milligrams of glucose reducing equivalents produced per min per liter of saliva (12).

$\alpha$-Amylase $p$-nitrophenyl $\alpha$-maltoside (PNPM) activity was determined using a new direct spectrophotometric method (12). Reaction conditions for this assay were optimized for possible CF factor inhibition of $\alpha$-amylase. The $1-\mathrm{ml}$ reaction mixture contained $0.5 \mathrm{ml}$ whole saliva supernate. The reaction rate is first order with respect to PNPM substrate concentration. $\alpha$-Amylase activity in PNPM units per liter is defined as micromoles of $p$ nitrophenol produced per min per liter of saliva at a substrate concentration of $1.0 \mathrm{mM}(12)$.

The protein content of saliva (milligrams of protein per $\mathrm{ml}$ saliva) was determined using Miller's (20) modification of the Lowry procedure (16). Amylase specific activity is defined as starch units per $\mathrm{mg}$ protein.

The following materials were purchased from the noted suppliers: PNPM, Regis Chemical Company, Morton Grove, IL; $p$ nitrophenol, Calbiochem, A Grade; starch, Merck soluble starch; gelatin, J. T. Baker, USP grade. All other reagents were of commercially available reagent grade or better. Absorbance was measured with a Gilford 240 recording spectrophotometer, equipped with a thermostatted cell compartment, automatic cell changer, and a digital readout. $\mathrm{pH}$ values were measured at ambient room temperature, $22-24^{\circ}$, with a Radiometer PHM62 standard $\mathrm{pH}$ meter. Distilled deionized water was used to prepare all solutions.

Multiple regression analysis was done using the BMDPIR program (7) at the Health Sciences Computing Facility, UCLA.

\section{RESULTS}

\section{INHIBITION OF CF $\alpha$-AMYLASE}

Salivary $\alpha$-amylase action on starch and PNPM has been compared to determine whether CDF in saliva could be detected by alterations in $\alpha$-amylase catalytic activity. To determine whether CDF inhibits $\alpha$-amylase in saliva, a recently developed assay (12) which should be most sensitive to inhibition was used. For simple enzyme kinetics, one of three types of inhibition patterns are usually observed: noncompetitive, competitive, and uncompetitive (15). These three modes of inhibition have different sensitivities to the inhibitor at different substrate concentrations. The patterns are summarized for saturating and first order substrate concentrations in Table 1.

The starch assay is done under saturating substrate concentration and a 1:4000 dilution of saliva in the reaction mixture. At this dilution the CDF does not affect the amylase starch activity (11). Therefore, the starch activity serves as a measure of the total uninhibited salivary amylase activity.

The PNPM activity is determined under first order substrate conditions, with a 1:1 dilution of saliva (12). These conditions of

Table 1. Effect of inhibitors at saturating and first order substrate concentrations

Limit for saturating sub- Limit for first order in substrate $\mathrm{S}>\mathrm{K}_{\mathrm{m}} \quad$ strate $\mathrm{K}_{\mathrm{m}}>\mathrm{S}$

\begin{tabular}{|c|c|c|c|c|}
\hline \multirow[b]{2}{*}{$\begin{array}{c}\text { Type of } \\
\text { inhibition }\end{array}$} & \multicolumn{2}{|c|}{ strate $S \gg K_{m}$} & \multicolumn{2}{|c|}{ strate $K_{m} \gg S$} \\
\hline & $v_{i} / v_{o}$ & $\begin{array}{l}\text { Observed } \\
\text { inhibition }\end{array}$ & $V_{i} / V_{o}$ & $\begin{array}{l}\text { Observed } \\
\text { inhibition }\end{array}$ \\
\hline Noncompetitive & 1. & Maximum & 1 & Maximum \\
\hline & $\overline{1+i / K_{i}}:$ & & $\overline{1+\mathrm{i} / \mathrm{K}_{i}}$ & \\
\hline Competitive & 1 & None & $\frac{1}{1+i / K}$ & Maximum \\
\hline Uncompetitive & $\frac{1}{1+\mathrm{i} / \mathrm{K}_{\mathrm{i}}}$ & Maximum & 1 & None \\
\hline
\end{tabular}

${ }^{1} \mathrm{~S}$ : substrate concentration; $\mathrm{K}_{\mathrm{m}}$ : Michaelis constant $(15) ; \mathrm{K}_{\mathrm{i}}$ : dissociation constant of the inhibitor from the enzyme; $V_{i} / V_{0}$ : ratio of reaction rates in the presence and absence of inhibitor; $i$ inhibitor concentration.
Table 2. Effect of CDF and Tris on $\alpha$-amylase PNPM activity

\begin{tabular}{lcccc}
\hline & $\begin{array}{c}\text { CDF effect, PNPM } \\
\text { units/starch units }\end{array}$ & $\begin{array}{c}\text { Tris effect, \% inhibi- } \\
\text { tion by } 90 \mathrm{mM} \text { Tris }\end{array}$ \\
\cline { 2 - 5 } $\begin{array}{c}\text { Saliva sample } \\
\text { genotype }\end{array}$ & $n$ & $\begin{array}{c}\text { (mean } \pm \text { SD) } \\
\times 10^{-5}\end{array}$ & $n$ & Mean \pm SD \\
\hline CF patients (CF) & 24 & $8.8 \pm 1.4$ & 6 & $66 \pm 4$ \\
CF parents (H) & 21 & $9.3 \pm 1.4$ & 6 & $62 \pm 10$ \\
Normal controls (N) & 28 & $9.2 \pm 1.5$ & 6 & $64 \pm 11$ \\
\hline
\end{tabular}

low substrate and high CDF concentration should be close to the optimum for detection of either noncompetitive or competitive CDF inhibition (Table 1). Uncompetitive inhibition will not be detected by comparison of the starch and PNPM activities. This mode of inhibition would be detected by comparing the PNPM activities under first order and non-first order substrate conditions.

The effect of Tris on the $\alpha$-amylase activity as measured by the starch and PNPM assays confirms that amylase does differ in its sensitivity to inhibitors under the two sets of reaction conditions. Tris $(90 \mathrm{mM})$ inhibits starch hydrolysis minimally $(11 \pm 10 \%)$, but markedly inhibits PNPM hydrolysis $(64 \pm 11 \%)$. This indicates that Tris is a competitive inhibitor of $\alpha$-amylase. A Dixon plot (6) at six Tris concentrations from $0-180 \mathrm{mM}$ yields a $\mathrm{K}_{\mathrm{i}}$ of $59 \pm 10$ $\mathrm{mM}$ for Tris inhibition of amylase PNPM activity.

The ratio of PNPM activity to starch activity for $C F, H$, and $N$ saliva would indicate whether the $C D F$ in $C F$ and $H$ saliva acts as a competitive or noncompetitive inhibitor of the amylase PNPM activity (Table 2). The $C F$ and $N$ values are not significantly different. Thus there is neither competitive nor noncompetitive inhibition of PNPM $\alpha$-amylase activity by CDF. This was examined more vigorously by analysis of variance of the regression coefficients of PNPM units vs. starch units over the three groups. Neither the slopes nor the intercepts differed among the groups $(P=0.920)$. We must conclude that even under reaction conditions which should be most sensitive to CDF inhibition of amylase activity, the association of CDF and amylase does not have any effect on amylase catalytic activity. This conclusion is confirmed by the observation that $90 \mathrm{mM}$ Tris has the same effect on PNPM activity of $\mathrm{CF}, \mathrm{H}$, and $\mathrm{N}$ saliva (Table 2). CDF has no detectable effect on either PNPM or Tris binding to $\alpha$-amylase.

\section{SALIVARY AMYLASE LEVELS}

To further characterize CF saliva samples, the amylase starch activity and protein concentration in $\mathrm{CF}, \mathrm{H}$, and $\mathrm{N}$ saliva were compared (Table 3). Although the mean amylase and protein concentrations for CF saliva were found to be higher than the means of the normal saliva ( $P<0.001$ and $P<0.005$, respectively), the specific activities were not significantly different (by Student $t$-test).

The distribution of values for amylase and protein concentration in $\mathrm{CF}, \mathrm{H}$, and $\mathrm{N}$ saliva is indicated in Figure 1. The large range of values is not due to fluctuations in composition of individuals, saliva. Up to eight determinations were made on repeated samples from 17 individuals. Samples were taken during different visits to the clinic or laboratory. Repeated determinations varied by less than I SD of the respective genotype mean.

\section{COMPARISON BY AGE AND SEX}

The amylase specific activity for normal samples appears to peak in preadolescence, and then drops sharply during adolescence (linear regression vs. age, $P=0.032$ ) (Fig. $2 A$ ). The heterozygote samples, from a necessarily older population, are similar to normal adults. CF samples show a drop similar to the normal subjects as age increases from 8-13 years, but have increased activity in the 14-24 year age group. This increase is due entirely to the fact that teenage $C F$ females have elevated amylase specific activity compared to all other groups $(P<0.005)$ (see Fig. 3, $A$ and $D$ ).

Salivary protein concentration appears to be increased for the 
Table 3. Amylase activity and protein concentration of whole saliva ${ }^{1}$

\begin{tabular}{|c|c|c|c|c|c|}
\hline & $n$ & Mean age (range) & $\begin{array}{c}\text { Amylase conc, }^{\prime} \\
\text { starch units } / \mathrm{ml} \pm \mathrm{SD}\end{array}$ & $\begin{array}{l}\text { Protein conc, }^{2} \\
\mathrm{mg} / \mathrm{ml} \pm \mathrm{SD}\end{array}$ & $\begin{array}{l}\text { Amylase sp act, } \\
\text { units } / \mathrm{mg} \pm \mathrm{SD}\end{array}$ \\
\hline CF & 25 & $17.4(05-30)$ & $56 \pm 37^{3}$ & $0.74 \pm 0.64^{4}$ & $106 \pm 72$ \\
\hline Male & 14 & $17.7(05-30)$ & $51 \pm 40^{4}$ & $0.78 \pm 0.76$ & $98 \pm 77$ \\
\hline Female & 11 & $16.9(09-27)$ & $64 \pm 31^{5}$ & $0.68 \pm 0.45$ & $116 \pm 64^{6}$ \\
\hline Heterozygote & 24 & $36.5(20-58)$ & $40 \pm 28$ & $0.62 \pm 0.39$ & $79 \pm 47$ \\
\hline Male & 5 & $37.8(22-57)$ & $17 \pm 13^{7,8}$ & $0.38 \pm 0.31$ & $84 \pm 82$ \\
\hline Female & 19 & $35.2(20-58)$ & $47 \pm 28^{8}$ & $0.68 \pm 0.38^{7}$ & $78 \pm 31^{6}$ \\
\hline Normal & 42 & $17.7(05-43)$ & $32 \pm 16^{3}$ & $0.48 \pm 0.34^{4}$ & $97 \pm 69$ \\
\hline Male & 24 & $17.8(06-43)$ & $31 \pm 12^{4.7}$ & $0.52 \pm 0.35$ & $109 \pm 89$ \\
\hline Female & 18 & $16.4(05-38)$ & $34 \pm 20^{5}$ & $0.43 \pm 0.31^{7}$ & $97 \pm 50$ \\
\hline
\end{tabular}

' Determined using starch assay. See Materials and Methods.

${ }^{2}$ Determined using Miller's modification (20) of the Lowry procedure (16).

${ }^{3} \mathrm{CF}$ vs. N, $P<0.001$

${ }^{4} \mathrm{CF}$ vs. N, $P<0.05$

${ }^{5}$ CF vs. N, $P<0.005$

${ }^{6} \mathrm{CF}$ vs. $\mathrm{H}, P<0.05$

${ }^{7} \mathrm{H}$ vs. $\mathrm{N}, P<0.05$

${ }^{8} \mathrm{H}$ females $v$ s. $\mathrm{H}$ males, $P<0.05$.

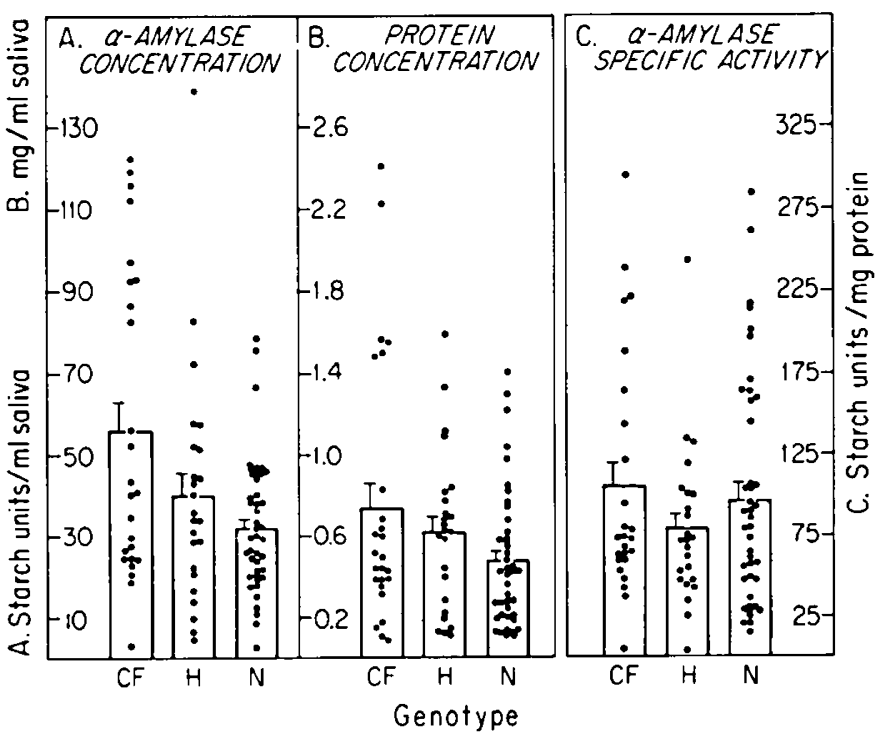

Fig. 1. $A$ : distibution of $\alpha$-amylase concentration values for each genotype. Amylase activity was determined using the starch assay as described under Materials and Methods. B: protein concentration values by genotype. $C$ : amylase specific activity values by genotype. The bars represent the mean \pm SEM for each genotype.

CF samples in the 14-24 year age group (Fig. 2B). This increase is due to the increased salivary protein concentration of adolescent CF males compared to all other groups $(P<0.005)$ (Fig. 3, $B$ and $E)$. Heterozygote mean values fall within the large normal range (Fig. 2B)

The greatest difference between $\mathrm{CF}$ and $\mathrm{N}$ samples is in the amylase concentration per $\mathrm{ml}$ saliva. Both male and female $\mathrm{CF}$ homozygotes have highly elevated salivary amylase concentration in the 14-24 year age group $(P<0.001$ ) (Fig. $3, C$ and $F$ ). The normal samples show no significant variation over the age range studied $(5-42$ years, $P=0.941)$. The heterozygote sample values appear to increase with age (linear regression for heterozygote females vs. age, $P=0.016$ ) but more $H$ samples as well as $\mathrm{N}$ samples in the older age range are needed to determine the significance of the apparent increase.

\section{AMYLASE HYPERSECRETORS}

The elevation of mean CF amylase concentration (Table 3 ) and protein content can be attributed to a group of amylase hyperse- cretors (Fig. 1). CF values are distributed in a bimodal fashion, such that the values are either in the normal range or are markedly elevated. Sixteen of $25 \mathrm{CF}$ patients had amylase concentrations within two SDs of the $\mathrm{N}$ mean; the remaining 9 values were 3 or more SDs above the N mean (Fig. 1). Similarly, 19 of $25 \mathrm{CF}$ protein values were in the range of the $\mathrm{N}$ mean $\pm 2 \mathrm{SD}$, whereas the other 7 values were higher than the maximum $N$ values. The protein hypersecretors were also amylase hypersecretors, so that the specific activity of salivary amylase in CF patients was neither bimodal nor different from the $\mathrm{N}$ mean.

\section{CF-PARENT CORRELATION}

All nine amylase hypersecretors were found in the 14-24 year age group. However, three patients in this age group were not hypersecretors. To determine whether hypersecretion is related to hereditary factors or to the clinical status of the patient, CF values were correlated to parent values and to Schwachman scores (25). For 11 patient-parent pairs, patient and parent ages were strongly correlated: $P=0.0017$. Amylase concentrations were marginally correlated $(P=0.075)$, but protein concentration and amylase specific activity were not correlated for the two groups.

Our patient population included one affected sibling pair. Both the 15-year-old female and her 12-year-old brother had normal amylase concentration (35 and 19 starch units $/ \mathrm{ml}$ ) and protein content $(0.440$ and $0.438 \mathrm{mg} / \mathrm{ml})$. This along with the weak patient-parent correlation of amylase concentration is consistent with some genetic influence on hypersecretion. However, data on additional affected sibling pairs is needed to define the genetic relationship to hypersecretion.

\section{SHWACHMAN SCORE CORRELATION}

The clinical status of the CF patients (assessed by the Shwachman score $(25))$ correlated marginally $(P=0.068)$ with the amylase concentration. The protein and specific activity values did not correlate significantly with the clinical status of the patients.

As expected, the age of the patient and the Shwachman score were correlated $(P=0.0011)$. The regression of Shwachman score $v s$. age for males had a slope of one half that observed for the females: $\mathrm{y}=87-1.2 \mathrm{x}$ vs. $\mathrm{y}=89-2.0 \mathrm{x}$. The regression lines for the two sexes were different $(P=0.029)$. A sharper decline in female $v$ s. male CF patients with age has been suggested previously $(24,31)$.

\section{DISCUSSION}

The CDF fraction isolated from $\mathrm{CF}$ and $\mathrm{H}$ saliva has been found to inhibit mammalian debranching enzyme (11). This activ- 
ity of the CDF has allowed replacement of the unwieldy and erratic oyster gill bioassay for CDF activity (4) with a quantitative enzymatic assay for salivary CDF activity (11). Unfortunately, this procedure requires prior separation of the CDF fraction from the salivary amylase, since amylase destroys the debranching enzyme substrate. This separation is cumbersome and the stability of CDF under the conditions of separation is unknown. Therefore, this assay retains major shortcomings.

Ideally, an enzymatic assay for CDF would use patient materials directly. Since amylase is already present in saliva, and since it is closely associated with the salivary $\operatorname{CDF}(1,8,9,11)$, the effect of CDF on this enzyme was studied. Unlike its action on the debranching enzyme, CDF was found to have no detectable effect on $\alpha$-amylase even under reaction conditions designed for maximum competitive and noncompetitive inhibition. Neither the amylase catalytic activity nor its binding to Tris is altered by the presence of CDF.

The 1:1 dilution used may not be a sufficiently high concentration of CDF to affect $\alpha$-amylase catalytic activity. The debranching enzyme is about 5 times more sensitive to Tris inhibition than is $\alpha$-amylase $\left(\mathrm{K}_{\mathrm{i}}=12 \mathrm{mM}(13)\right.$ and $\mathrm{K}_{\mathrm{i}}=59 \mathrm{mM}$, respectively). The concentrated CDF fraction from larger quantities of saliva may yet be found to affect $\alpha$-amylase activity. However, for direct measurements on $C F$ body fluids, a more sensitive assay must be developed. Although the CDF and $\alpha$-amylase are closely associated in CF saliva, their mode of interaction remains to be defined.

To provide information on the basis for elevated $\alpha$-amylase levels in CF, the amylase activity and protein concentration of $\mathrm{CF}, \mathrm{H}$, and $\mathrm{N}$ saliva samples were compared as a function of age and sex. Our results (Table 1 ) indicate that mean salivary amylase concentration and protein content are in the order $\mathrm{CF}>\mathrm{H}>\mathrm{N}$, with overlap of values among the groups.

The magnitude of the difference between $\mathrm{CF}$ and $\mathrm{N}$ values is

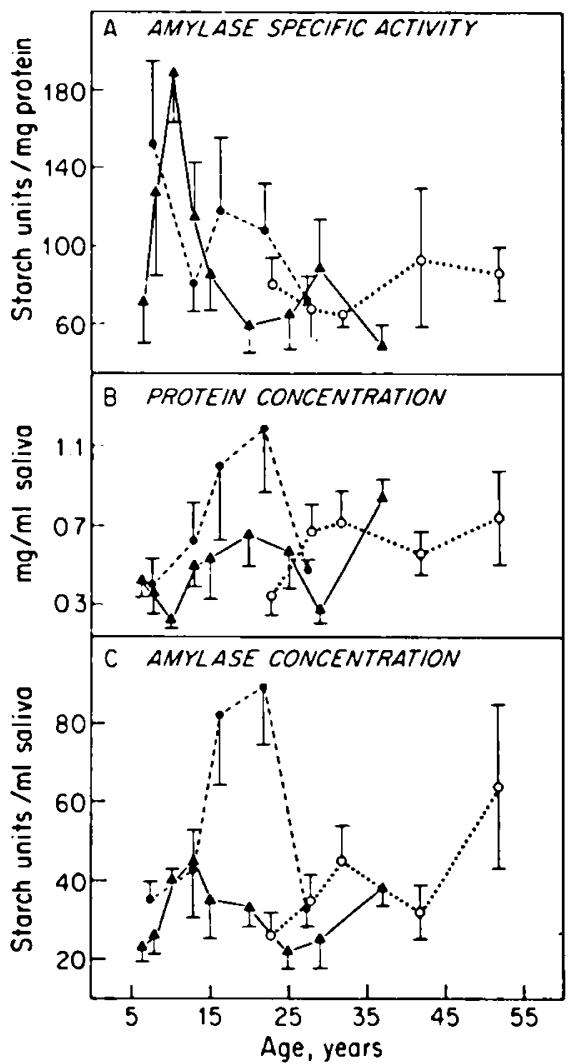

Fig. 2. Salivary amylase and protein content by age and genotype. Each point corresponds to the mean \pm SEM of four or five individual values, plotted vs. their mean age. $\mathrm{CF}, \mathbf{-}--\mathrm{H}, \mathrm{O} \ldots \mathrm{O} ; \mathrm{N}, \mathbf{\Delta - \Delta}$. $A$ : amylase specific activity; $B$ : protein concentration; $C$ : amylase concentration in starch units per $\mathrm{ml}$.

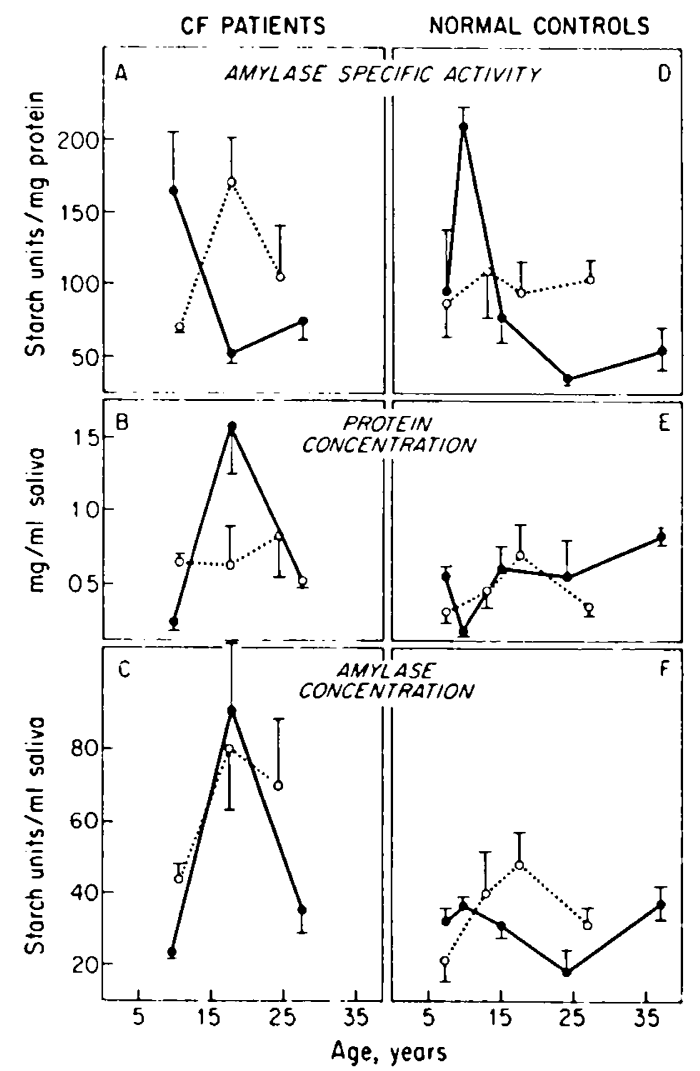

Fig. 3. Comparison of male and female salivary composition for $\mathrm{CF}$ and $\mathrm{N}$ samples. Each point corresponds to the mean \pm SEM for three to five individuals, plotted vs. their mean age. Males, - females, O...O. $A$ : amylase specific activity of CF samples; $B$ : protein content of $C F$ samples; $C$ : amylase concentration of CF samples; $D$ : amylase specific activity of $\mathrm{N}$ samples; $E$ : protein content of $\mathrm{N}$ samples; $F$ : amylase concentration of $\mathrm{N}$ samples.

age dependent (Fig. 2). This variation with age explains previously described differences between $C F$ and $N$ saliva $(2,3,17)$. For example, Blomfield's group reported that amylase concentration was elevated in the parotid saliva of a group of 3- to 17-year-old CF patients (2). Some of Blomfield's patients were hypersecretors. The same group subsequently reported that amylase levels in 9to 13-year-old CF patients were not significantly different from the $\mathrm{N}$ mean (3). We save found a sharp increase in $\mathrm{CF}$ whole saliva amylase concentration in patients between 14 and 24 years of age $(P<0.005)$. The cause for this difference between $C F$ children, adolescents, and young adults remains to be determined. Normal saliva shows no significant change in amylase concentration from 5-42 years of age.

In contrast to the constant amylase concentration of normal saliva, the mean specific activity of normal saliva decreases dramatically with increasing age $(P=0.032)$ (Fig. 2). CF males show a similar decrease (Fig. 3 ) but CF females demonstrate an increase in specific activity which peaks at 17 years. This change with age may represent the functional development of the various salivary glands (26) and possible hormonal influences ( $c f$. Ref. 26) which depend upon both age and sex. In any event, these data emphasize the need for age- and sex-matched controls in all studies of salivary composition.

The existence of a subgroup of amylase hypersecretors in the $\mathrm{CF}$ patient population is another example of the heterogeneity of this disease. The basis for hypersecretion of amylase in CF remains to be elucidated. Both hereditary and clinical factors are marginally correlated to the elevated amylase concentrations. The high amylase values suggest that the parotid gland may be secreting a higher proportion of the whole saliva than normal. One might invoke three hypotheses to account for this. First, the parotid 
gland may be contributing a greater portion of the whole saliva because of plugging of the mucus-secreting glands. This type of plugging in the pancreas accounts for progressive loss of pancreatic exocrine function in CF $(5,31)$. Second, the parotid gland may hypersecrete in order to maintain the serum amylase levels. Serum pancreatic amylase is decreased in CF patients with pancreatic insufficiency yet the total serum amylase is maintained in the normal range by salivary isozymes $(26,29,30)$. If this is the case, hypersecretion of amylase in CF saliva may prove to be a sensitive, indirect measure of deteriorating pancreatic exocrine function. Third, amylase hypersecretion may be more directly related to a primary defect in the secretory mechanism in CF. Amylase release is mediated by intra- and extracellular $\mathrm{Na}^{+}$and $\mathrm{Ca}^{2+}(22)$. Alterations in electrolyte transport or permeability could affect secretory function. Amylase secretion is altered in cystic fibrosis. Its role in the pathophysiology of the disease remains to be determined.

\section{REFERENCES AND NOTES}

1. Bishop, S. H., Reinig, M. J., and Doggett, R. G.: Chromatographic isolation of cystic fibrosis salivary isoamylases, Cystic Fibrosis Club Abstracts, Vol. 14, p. $25,1973$.

2. Blomfield, J., Allars, H. M., Rush, A. R., van Lennep, E. W., and Brown, J. M.: Parotid serous hypersecretion in cystic fibrosis. Aust. Paediat. J., 10:75 (1974).

3. Blomfield, J., Rush, A. R., Allars, H. M., and Brown, J. M.: Parotid gland function in children with cystic fibrosis and child control subjects. Pediat. Res., 10: 574 (1976).

4. Bowman, B. H., Lockhart, L. H., and McCombs, M. L.: Oyster ciliary inhibition by cystic fibrosis factor. Science, 164: 325 (1969).

5. di Sant Agnese, P. A., and Talamo, R. C.: Pathogenesis and physiopathology of cystic fibrosis of the pancreas. N. Engl. J. Med., 277: 1344 (1967).

6. Dixon, M.: The determination of enzyme inhibitor constants. Biochem. J., 55: 170 (1953).

7. Dixon, W. J. (ed.): BMDP: Biomedical Computer Programs. University of California Press, Los Angeles, 1975.

8. Doggett, R. G., and Harrison, G. M.: Cystic fibrosis: in vivo reversal of the ciliostatic character of serum and parotid secretions by heparin. Cystic fibrosis in vitro reversal of the ciliostatic character of serum and salivary secretions by heparin. Nature New Biol., 243: 250, 251 (1973).

9. Doggett, R. G., and Harrison, G. M.: Cystic fibrosis: Reversal of ciliary inhibition in serum and saliva by heparin. Tex. Rep. Biol. Med., 31: 687 (1973).

10. Fisher, E. H., and Stein, E. A.: $\alpha$-Amylase from human saliva. Biochem. Prep., 8: 27 (1961).

11. Gillard, B. K., Feig, S. A., Harrison, G. M., and Nelson, T. E.: Cystic fibrosis: Enzymatic detection of a ciliostatic factor. Pediat. Res., 10: 907 (1976).

12. Gillard, B. K., Markman, H. C., and Feig, S. A.: A direct spectrophotometric procedure for determination of $\alpha$-amylase activity in saliva using $p$-nitrophenyl $\alpha$-maltoside as substrate. Clin. Chem., 23: 2279 (1977)

13. Gillard, B. K., and Nelson, T. E.: Amylo-1,6-Glucosidase/4- $\alpha$-glucanotransferase: Use of reversible substrate model inhibitors to study the binding and active sites of rabbit muscle debranching enzyme. Biochemistry, 16: 3978 (1977).

14. Howell. D. A. Chairman: Report of the Committee for a Study for Evaluation of Testing for Cystic Fibrosis. J. Pediat.. 88: 711 (1976).

15. Lehninger, A. L.: Biochemistry, Ed. 2, pp. 197-201 (Worth Publishers, Inc., New York, 1975).
16. Lowry, W. H., Rosebrough, N. J., Farr, A. L., and Randall, R. J.: Protein measurements with the Folin phenol reagent. J. Biol. Chem., 193: 265 (1951).

17. Mandel, I. D., Kutscher, A., Denning, C. R., Thompson, R. H., and Zegarelli, E. V.: Salivary studies in cystic fibrosis. Amer. J. Dis. Child., 113: 431 (1967).

18. Mayo, J. W., Wallace, W. M.. Matthews, L. W., and Carlson. D. M.: Quantitation of submandibular proteins resolved from normal individuals and children with cystic fibrosis. Arch Biochem. Biophys., 175: 507 (1976).

19. McNeely, C., and Bowman, B. H.: Cystic fibrosis: Is the ciliary inhibitor present in the urine? Cystic Fibrosis Club Abstracts, Vol. 16, p. 6, 1975.

20. Miller, G. L.: Protein determination for large numbers of samples. Anal Chem., 31: 864 (1959).

21. Nelson, T. E., Gillard, B. K., and Bishop, S. H.: Salivary $\alpha$-amylase and the role of polyamine binding to carbohydrases in cystic fibrosis ciliostasis. Cystic Fibrosis Club Abstracts, Vol. 15, p. 7, 1974.

22. Poulsen, J. H., and Williams, J. A.: Effects of the calcium ionophore A23187 on pancreatic acinar cell membrane potentials and amylase release. J. Physiol., 264: 323 (1977).

23. Robyt. J. F., and Whelan, W. J.: The $\alpha$-amylases. In J. A. Radley: Starch and Its Derivatives, Ed. 4, p. 431 (Chapman and Hall, London. 1968).

24. Shwachman, H., Kowalski, M., and Khaw, K-T.: Seventy patients with cystic fibrosis over twenty-five years of age-A new outlook. Cystic Fibrosis Club Abstracts, Vol. 16, p. 196, 1975.

25. Shwachman, H., and Kulczycki, L. L.: Long-term study of 105 patients with cystic fibrosis. Studies made over 5 to 14 year period. Amer. J. Dis. Child., 96: 6 (1958).

26. Skude, G.: Sources of serum isoamylases and their normal range of variation with age. Scand. J. Gastroenterol., 10: 577 (1975).

27. Smith, Q. T., Shapiro, B. L.. Hamilton, M. J., and Biros, M.: A parotid salivary protein present during late pregnancy and postpartum. Proc. Soc. Exp. Biol. Med., 153: 241 (1976).

28. Spock, A., Heick, H. M. C. Cress, H., and Logan. W. S.: Abnormal serum factor in patients with cystic fibrosis of the pancreas. Pediat. Res.. I: 173 (1967).

29. Townes, P. L.. Moore, W. D., and White, M. R.: Amylase polymorphism: Studies of sera and duodenal aspirates in normal individuals and in cystic fibrosis. Amer. J. Hum. Genet., 28: 378 (1976).

30. Wolf, R. O., Taussig. L. M., Ross, M. E., and Wood. R. E.: Quantitative evaluation of serum pancreatic isoamylases in cystic fibrosis. J. Lab Clin. Med., 87: 164 (1976).

31. Wood, R. E., Boat, T. F., and Doershuk, C. F.: State of the art: Cystic fibrosis. J. Lab Clin. Med., 87: 164 (1976).

32. The mammalian debranching enzyme possesses two activities, transferase $(1,4$ $\alpha$-D-glucan 1,4- $\alpha$-D-glucan 4- $\alpha$-glycosyltransferase, EC 2.4.1.25) and glucosidase (dextrin 6- $\alpha$-glucosidase, EC 3.2.1.33). Properties of this enzyme have been reviewed by Lee, E. Y. C.. and Whelan, W. J.: The Enzymes, Vol. 5. p. 191 (1971). Inhibition studies on this enzyme are described in Ref. 12.

33. We wish to thank Charles Markman. M.D.. Alan Osher, M.D., and Susan Pedersen, R.N. for assistance in collecting the saliva samples. Dr. Osher alsu provided the Schwachman scores. We also wish to thank Dr. Thomas F. Dolan, Jr., for stimulating discussions. The excellent assistance of Mrs. Jo Eggenweiler and Mrs. Mary Forest in the preparation of this manuscript is also greatly appreciated.

34. A preliminary report of this work has appeared as an abstract read by title at the Cystic Fibrosis Club Eighteenth Annual Meeting, San Francisco. 1977, p. 43.

35. This research was supported by a National Research Service Award (NIH I F32 HL 05506) to BKG, and by the Karen Brigham Memorial Fund. Computing assistance was obtained from the Health Sciences Computing Facility, UCLA. supported by NIH Special Research Resources Grant RR-3.

36. Requests for reprints should be addressed to: B. K. Gillard. Ph.D., Department of Pediatrics, School of Medicine, University of California, Los Angeles, CA 90024 (USA).

37. Received for publication September 2, 1977.

38. Accepted for publication November 2, 1977. 